\title{
The legal system for horse protection in ancient China
}

\author{
Li-hong Gao \\ Professor of Law School of Zhongnan University of Economics and Law, Vice President of China Society \\ of Environmental Resources Law, President of Hubei Province Society of Environmental Resources Law, \\ China
}

$\mathrm{Da} \mathrm{Su}$

Ph.D. student of Environmental Law, Zhongnan University of Economics and Law, China

Recommended citation. GAO, L., SU, D. The legal system for horse protection in ancient China, dA. Derecho Animal (Forum of Animal Law Studies) 12/3 (2021). - DOI https://doi.org/10.5565/rev/da.565

\begin{abstract}
The concept of "animal welfare" originated relatively recently and refers to fulfilling the basic needs of animals to avoid unnecessary suffering. However, in ancient China, ecological awareness similar to current "animal welfare" had already been awoken and codified in the form of a series of legal systems, among which were specific regulations for horses that entailed giving them a good life, as well as a series of "animal welfare" regulations more in line with the current sense, such as not hitting them in the face, nor using genetically related horses for breeding. This paper analyses the current legal framework of animal protection to trace the legal system on horse protection throughout the history of China.
\end{abstract}

Keywords: animal protection; legal system; history of the Chinese legal system; ancient codes.

Resumen - El sistema jurídico para la protección de los caballos en la antigua China

El concepto de "bienestar animal" tiene un origen relativamente reciente y hace referencia a satisfacer las necesidades básicas de los animales para evitar que sufran innecesariamente. Sin embargo, en la antigua China, la conciencia ecologista similar al actual "bienestar animal" ya se había despertado y codificado en forma de una serie de sistemas jurídicos. Entre ellas, unas normas específicas para los caballos que implican darles una buena vida, junto a una serie de normas de "bienestar animal" con un sentido más actual, como no golpearles en la cara y no utilizarlos para crianza cuando estén relacionados genéticamente. Este documento analiza el marco jurídico actual de protección animal para trazar el sistema jurídico de la protección de caballos en la historia de China.

Palabras clave: protección animal; sistema juridico; historia del sistema juridico chino; códigos antiguos. 


\section{Contents}

1. Introduction

2. Horse registration regime

3. Horse feeding regime

4. Horse farms regime

5. Horse domestication regime

6. Institutional management regime

7. Horse breeding and medical care regime

8. Setting of legal liability

9. Conclusion and Prospects

\section{Introduction}

According to the OIE Terrestrial Animal Health Code, there are five basic principles of animal welfare: freedom from hunger, thirst and malnutrition, freedom from fear and stress, freedom from physical discomfort and thermal discomfort, freedom from pain, injury, and disease, and freedom to express standard patterns of behavior. ${ }^{1}$ The ancient Chinese ideology advocates recognizing the moral status of animals, behind which is the non-confrontational relationship between humans and animals under the agricultural civilization. The concrete manifestation of this was the legal protection of all kinds of livestock. ${ }^{2}$ Among them, horses belong to the first order of legal protection for animals. Xiu Ou-yang has said, "The day when the Heaven takes away the horses, the country's military instrument, the country will perish."(马者，国之武备，天去其备，国将 危亡。 $)^{3}$. Horses had multiple special functions in ancient China. Horses were military combat tools related to the country's armament strength, and they were also the primary means of transportation.

For this reason, China has established the legal protection of horses since the pre-Qin dynasty. The five major principles of modern animal welfare are addressed in the specific regulations. ${ }^{4}$ Through combing various documents in Chinese history, this paper focuses on the legal concern for the horse as an animal and argues that a series of specific legal regimes were formed, including horse registration, horse feeding, horse farms, horse domestication, management institutions, and care and medical regimes, throughout the whole process of raising and using horses, and strict legal responsibilities were formed, reflecting a certain degree of the modern meaning of animal welfare legal awareness. By reviewing the many ancient classics from China's dynastic past, this article focuses on the legal concern for the horse as an animal. It argues that a series of specific legal regimes were formed. These regimes contained stipulations related to horse registration, horse feeding, horse breeding, horse domestication, institutions for horse management, and required practices for horse care and medical attention in the entire lifecycle from its rearing to its use. We argue that these legal

\footnotetext{
* This paper involves many ancient Chinese texts and literary texts, and since there is a great difference between literary texts and modern Chinese expressions, we have attached the original text of the literary texts involved to the English translation version so that readers can read and inquire. The same method is also used for the titles of ancient books and literature sources. We would like to express sincerest gratitude to the anonymous reviewers and editorial team.

* Supported by "the Fundamental Research Funds for the Central Universities", Zhongnan University of Economics and Law (Grant Number:2722021EG004). Major projects of National Social Science Foundation of China (Grant Number: 20ZDA090).

${ }^{1}$ See Chapter 7.1 Article 7.1.2 of the OIE Terrestrial Animal Health Code : https://www.oie.int/index.php?id=169\&L=0\&htmfile=chapitre_aw_introduction.htm.

${ }^{2}$ The concept of legal culture was introduced by Zhi-ping LIANG, who argued that "what ancient Chinese law reflects is the quality of traditional Chinese culture." In a nutshell, ancient Chinese law has its own special conceptual form, value judgment and behavior pattern. See LIANG, Z., Legal Discernment: The Past, Present and Future of Chinese Law, Guiyang: Guizhou People's Publishing House (1992) 149.

${ }^{3}$ The original word for "nature" in Chinese is Tian (天). In our opinion, this concept has multiple meanings: first, it is close to the "laws of nature", symbolizing some kind of natural law that operates independently of human will; second, "nature" is given a personalized connotation, and on this level, it is similar to "god"; third, this natural attribute is not opposed to human beings, but on the contrary, the ancient Chinese believed that both nature and human beings are in the same moral world.

${ }^{4}$ High levels of animal welfare, on the other hand, require disease immunization and veterinary treatment, appropriate housing, management, nutrition, humane treatment and humane slaughter. See Chapter 7.1 of the OIE Terrestrial Animal Health Code : https://www.oie.int/index.php?id=169\&L=0\&htmfile=chapitre_aw_introduction.htm.
} 
regimes also contained strict legal responsibilities that looked like the archaic ideas of the modern concept of animal welfare, indicating Chinese a wareness of animal welfare in ancient times.

\section{Horse registration regime}

As early as the Spring and Autumn Period (Among 770 B.C 476 B.C) and the Warring States period (Among 476 B.C 221 B.C), ancient Chinese legislators formed a systematic legal system for the protection of horses, and the degree of perfection of this legal system is evident from the emergence of the horse registration regime. In the 25th year of the reign of Duke Xiang, it is written in the Tradition of Zuo that "the chariots were assigned to the horses and the horses were registered" (赋车籍马). ${ }^{5}$ It refers to registering their physical conditions such as age, body condition, and coat color. Through this universal census registration, the national center had a basic grasp of the current stock and overall situation of horses in the country and thus could better manage them.

In addition to the Tradition of Zuo, which can be regarded as the origin of horse registration, the Qin Law also stipulates that: "If the cattle, horses, and non-exchangeable objects are mislabeled, the official's staff will be fined one dun." (马牛误职(识)耳, 及物之不能相易者,赀官啬夫一盾), ${ }^{6}$ and "Miscalculation of the population of a household or more than one head of cattle and horses is a big mistake. If the person realizes the error on his own, the crime may be reduced by one degree." (人户、马牛一以上为大误.误自重也,减罪 一等 $)^{7}$. The operation of the horse registration regime was severely regulated.

In the Han Dynasty, the combination of horse registration regime and taxation administration occurred. In May 103 B.C, people recorded the number of horses in the population register for taxation. The tax on horses was either paid in money or directly with horses as credit. ${ }^{8}$

The horse registration as essential horse management and protection regime was inherited, with the development of China's ancient animal husbandry continuously improved. In the Tang Dynasty, the New History of the Tang Dynasty states: "Governor in various state pastures should record the quality of the horses in the book, and those of good quality were called "Zuo," and those of poor quality were called "You. "In July each year, the herdsmen combine the books of each state pastures into one and proofread them, and submit them to the Tai Pu Si in August." (马之驽良皆有籍, 良马称左, 驽马称右, 每岁孟秋,群牧使以诸监之籍合为 一, 以仲秋上于寺). ${ }^{9}$ The register of horses included the quality, age, and origin of the horses. It was started in the summer of each year and was summarized in the autumn of the year. ${ }^{10}$ The Tang Dynasty fixed this regime in a codified form. Later, the Song, Yuan, Ming, and Qing dynasties also inherited the regime, with only a few modifications in the details of the expression. The Tang Code also states that there must be two copies of the horse's register, one kept by the governor who manages the herd and one held by the governor who oversees the state pasture. ${ }^{11}$

The implementation of the horse registration regime is recorded in the Dunhuang documents. One of them is a record of 968 A.D. that counted the herd of camels, horses, cattle, and sheep. ${ }^{12}$ The account divides the herd into sires and mules in the record and records the age and number of horses. ${ }^{13}$

\section{Horse feeding regime}

The welfare protection of horses is more often found in the horse feeding regime. In the specific feeding process, the regime protected the instrumental value of the horse, and it also paid attention to the particular importance and welfare of each horse.

\footnotetext{
${ }^{5}$ Yu Du notes that: " Register the horse's coat color, age, and teeth for military use."(籍疏其毛色岁齿, 以备军用) (Qing Dynasty) RUAN, Y., Proofreading, Commentary on the Thirteen Classics/Shi San Jing Zhu Shu, Beijing: China Book Bureau (2009) 4312.

${ }^{6}$ The dun was the unit of currency in the Qin Dynasty. WANG, H., WANG, W., Chronological Supplement to Qin Unearthed Documents, Shui Hu Di Jian Jiao Lv, (《秦出土文献编年补订》) San Qin Press (2014) 235.

${ }^{7}$ WANG, H., WANG, W., Chronological Supplement to Qin Unearthed Documents, Shui Hu Di Jian Jiao Lv, San Qin Press (2014) 235.

${ }^{8}$ (Han Dynasty) BAN, G., The Book of the Han Dynasty, Beijing: China Book Bureau (2005)143.

${ }^{9}$ (Song Dynasty) XIU, O., The New History of the Tang Dynasty, Beijing: China Book Bureau (1975) 1255.

${ }^{10}$ Tai $\mathrm{Pu} \mathrm{Si}$ is an ancient Chinese central agency that mainly manages matters related to horses and other animals.

${ }^{11}$ See Draft translation of the 'Tian Sheng Ling-Jiu Mu Ling', Journal of Chinese Ancient Legal Literature Studies \{3\}.00 (2015)299333. doi: CNKI:SUN:GDFL.0.2015-00-012.

12 TANG, K., LU, H., The Interpretation of Authentic Dunhuang Socio-Economic Documents $\{3\}$, National Library Microcopy Center of China (1990) 590.

${ }^{13}$ ZHANG, L., Exploring the grassroots labor groups of Tang dynasty state pastres. Jianghan Tribute\{3\}.04(2021)97-104. doi: CNKI:SUN:JHLT.0.2021-04-013.
} 
First, ancient China had strict requirements for the quality and quantity of feed for horses. In the Book of Songs, there is a record that " Horses for riding are kept in stables, and they are fed daily with mixed grains." (乘马在溉, 摧之秝之), ${ }^{14}$ and here the mixed grains specifically refers to finely chopped fodder forage. Article 198 of The Tang Code, "Being in Charge of Government Animals That Become Sick," stipulates that the local government was required to provide grain, hay, and medicine for sick animals. It directly references the type of fodder in the code, which shows the importance the legislator attached to the horses' feeding regime. The original text is as follows:

"SUBCOMMENTARY: According to the Statutes on Stables and Pastures: "If any government animal becomes sick on the road and is not capable of going on further, it should be left and entrusted to the nearest prefecture on the country, [the authorities of] which should care for it, feed it, and treat the sickness. The grain, hay, and medicine should be provided out of official funds." 15

In the Tang Dynasty, The Tang Liu Dian explicitly regulated the sources of feed for horses. For example, for the horses directly managed by the central government, their feed source was specified as the area within a 500-mile radius of the two capitals. ${ }^{16}$ According to the $W u Z i$, "The horse must be in a safe place with suitable water and grass and must be satisfied with its hunger" (马必安其处所,适其水草, 节其饱饥), ${ }^{17}$ meaning that the water and grass for the horse must be under its diet. There is a record that says: "The envoys brought the seeds and fruits (of grapes and alfalfa), so the people began to plant these two crops to make that horse camp fertile." (马嗜首营,汉使取其实来,于是天子始种营营、蒲陶肥饶地) ${ }^{18}$. People introduced forage species from the West to be planted during the Han Dynasty to improve forage for horses.

The Tang Liu Dian contains:

"The following feeder requirements need to be met when feeding the animals: Two feeders are responsible for one elephant. One feeder is responsible for one good quality horse, two medium quality horses, or three low-quality horses. In the case of camel, cow, or mule, one feeder is responsible for four simultaneously. About donkeys or pure colored animal hatchlings, one feeder is responsible for feeding six of them. In addition, one feeder can be responsible for 20 sheep at the same time." ${ }^{19}$ (诸系 饲, 象一头给丁二人, 细马一匹、中马二匹、驽马三匹、驼牛骡各四头、驴及纯犊各六头、 羊二十口各给丁一人。)

This entry in the Tang Liu Dian also details that the feeder needs to give different amounts of feed each day depending on the type and age of the animal. ${ }^{20}$ The standard of feeding horses was strictly regulated. The procedure and examination of feeding horses were also fixed in code, thus raising the country's bar of feeding horses.

In a record titled "Changxingfang Zhuang," the requirements of the feeding regime could be met in terms of the type of horse feed required at that time; however, the amount of specific feeding varied depending on the season and environment. For example, the amount of corn fed in winter when there is no grass does not meet the requirements of one Dou. ${ }^{21}$ Because the feudal economy fluctuated, it was challenging to meet such precise feeding requirements fully. ${ }^{22}$ In addition, the legislator specifically provided that for animals such as horses and donkeys involved in judicial cases, the official would be responsible for grazing them nearby during the judicial trial. ${ }^{23}$

Analyzing the specific operation of horses' diet also meets animal welfare requirements about the physiological welfare requirements in ancient China, and even more than ever. Qi Min Yao Shu stipulates that:

\footnotetext{
${ }^{14}$ (Qing Dynasty) RUAN, Y., Proofreading, Commentary on the Thirteen Classics/Shi San Jing Zhu Shu, Beijing: China Book Bureau (2009)1032.

${ }^{15}$ JOHNSON, W., The Tang Code, Princeton: Princeton University Press (1979) 183.

16 (Tang Dynasty) LI, L., TANG, L.D., CHEN, Z., Proofreading. Beijing: China Book Bureau (1992) 225.

17 (Qing Dynasty) MA, S., SHI, Y. (《绎史》卷一百五《战国第五·吴起仕相楚》), Beijing: China Book Bureau (2002) 2767.

${ }^{18}$ YU, T., The Two Han Dynasties, Wei Jin and North and South Dynasties: A Note on the Biography of the Western Regions( 《两 汉魏晋南北朝正史西域传校注》), Beijing: China Book Bureau (2005) 39.

${ }^{19}$ (Tang Dynasty) LI, L., Tang Liu DIAN, T.L., CHEN, Z., Proofreading. Beijing: China Book Bureau, (1992) 484.

${ }^{20}$ (Tang Dynasty) LI, L., DIAN, T.L., CHEN, Z., Proofreading. Beijing: China Book Bureau, (1992) 484.

${ }^{21}$ One Dou was some kind of unit of measurement at that time. One Dou is equal to about 12 pounds today.

${ }^{22}$ ZHANG, L., Exploring the grassroots labor groups of Tang dynasty state pastres. Jianghan Tribute $\{3\} .04(2021)$ 97-104. doi:CNKI:SUN:JHLT.0.2021-04-013.

${ }^{23}$ See Draft translation of the 'Tian Sheng Ling-Jiu Mu Ling', Journal of Chinese Ancient Legal Literature Studies \{3\}.00 (2015)299333. doi:CNKI:SUN:GDFL.0.2015-00-012.
} 
"Anyone using, riding cattle and horses, must take into account their physical ability; at the same time, the environment temperature and feeding, are in line with their natural needs."(及牛乘马,量其力能;寒温饮饲, 适其天性 $)^{24}$ It shows the awakening of a high degree of ecological consciousness under the guidance of "Min Bao Wu Yu "(民胞物与). ${ }^{25}$ We should ensure the survival of horses and empathize with them by giving them their natural favorite water and grass to enhance their welfare.

Lao Qi Da records the details of the time and steps for feeding the horses: "feeders should let the horse empty the stomach, and then slowly feed it. When the first feeding, feeders should mix the feed and water. Until 3:00 to 5:00 in the middle of the night and then feed it so that the horse will eat full and nutritious, if simply feed first, the horse will only pick material to eat, do not eat grass."(等马大控一会,慢慢的喂者.初喂 时, 则将料水拌与他, 到五更一发都与料吃, 那般时马每分外吃的饱, 若是先与料呵, 那马则拣了料吃, 将草 都抛撒了。 $)^{26}$.

For different physiological conditions of horses, people also summed up a rich set of feeding methods. For example, feeders should feed pregnant horses according to the following ways: "They must first eat grass, before drinking water, not allowed to feed the straw, millet grain, mixed grain and paddy tears and should be fed with sewage"(其骡马先须吃草, 后方可饮水,不许喂荞麦秸㯟攘杂粮并淘米沦,并一应污水喂养); Thinner horses need to be fed with cooked beans. ${ }^{27}$ The modern animal welfare theory requires freedom from hunger and thirst, which only provides food and water that makes the animal healthy. Although horses are still protected as property, a high degree of attention has been paid to their nature and preferences, which is an efficient way to preserve and utilize them.

\section{Horse farms regime}

All Chinese dynasties established the horse farms regime to keep horses in a centralized manner. Specifically, the model is to provide a vast place for horses to live and move around within a defined area and arrange a large number of office personnel to manage and ensure the safety of the horses. Among them, the official horse breeding industry occupies the absolute core. However, during particular periods, the pattern of horse breeding may change.

During the Han Dynasty, when the number of military horses was insufficient, the government strongly encouraged official and civilian horse breeding. ${ }^{28}$ The encouragement of horse breeding was even achieved by exemption from military service. ${ }^{29}$ At the same time, the government had strict legal restrictions on the sale of horses, and neither nobles nor officials were allowed to buy or sell horses at their discretion. ${ }^{30}$

A typical example of the horse farms regime is the Tang Dynasty's state pasture regime. "The horse is an important resource for armament; therefore, the state pastures to keep horses, the regime originated in the late. In the early Tang Dynasty, the official government got 2000 Turkic horses and 3000 horses leftover from the Sui Dynasty. So, the government moved them to Longyou, and this is the origin of the state pasture regime." (马者,兵之用也; 监牧所以蕃马也,其制起于近世。唐之初起, 得突厥马二千匹, 又得隋马三 千于赤岸泽, 徙之陇右, 监牧之制始于此。 ${ }^{31}$ Horse farms were given a high degree of economic support by the state.

From today's animal protection theory perspective, the ancient people were highly concerned about horses' living conditions when establishing horse farms. Even the practice at that time involved, to some extent, the welfare principle of "freedom of expression of nature." The History of the Song Dynasty has a comment on the location of the Tang Dynasty's state pastures: "This place was the site of the Tang Dynasty's Lou Fan state pasture, where the water and grass environmental conditions were suitable for horses. --- The

\footnotetext{
${ }^{24}$ (Northern Wei Dynasty) JIA, S., Qi Min Yao Shu, Beijing: China Book Bureau (2009) 493.

25 The meaning of "Min Bao Wu Yu" is that people are fellow citizens and things are of the same kind, and people need to have compassion and love for others and all things. This includes, of course, animals. (Song Dynasty) WEN, T., The Collected Poems of Wen Tianxiang, Beijing: China Book Bureau (2017) 219.

${ }^{26}$ Lao Qi Da is a material for people to learn Chinese during the ancient Wang's Goryeo and Lee dynasties, and the record here shows that the details of feeding horses were passed down among the people as a communication and teaching experience. FANG, Y., Notes on words in Lao Qi Da and Lao Qi Da Jilan, Journal of Hefei Normal University, 1 (2014) 10-13.

${ }^{27}$ Quoted from LI, S., LI, X., A Study of Official Horse Herding in the Ming Dynasty, Agricultural Archaeology, 03 (1999) $310-317$. doi:CNKI:SUN:NOSE.0.1999-03-046.

${ }^{28}$ (Han Dynasty) BAN, G., The Book of the Han Dynasty,Beijing:China Book Bureau (2005)127.

${ }^{29}$ LIU, X., Han Dynasty Tax on Six Animals: Origin, Implementation and Effects, The Journal of Chinese Social and Economic History, 2 (2014) 1-6.

${ }^{30}$ See SHANG, Y., The Evolution of National Horse Resources Genealogy and the Generation of Han and Tang Meteorology, Social Sciences in China, 8 (2020) 154-177.

${ }^{31}$ (Song Dynasty) XIU, O., Yhe New History of the Tang Dynasty, Beijing: China Book Bureau (1975) 1337.
} 
water and grass in the area of Hedong are suitable, and the terrain is very high, which is also suitable for the nature of horses ......" (其间水草最宜牧养, 此唐楼烦监地。......河东一路, 水草甚佳, 地势高寒, 必 宜马性。 ....... $)^{32}$ The site chosen for the state pastures in the Tang Dynasty is always suitable for horses and is generally accompanied by natural water and grass.

Xiu Ou-yang commented that the choice of grazing land in the Tang Dynasty was in line with the nature of horses. ${ }^{33}$ It is also stated in Jiu Mu Ling that when the number of horses in the state pasture reached 5000, the government would separately open a new state pasture. ${ }^{34}$

Specifically, the horse farms regime was based on the provision of a large defined area for horses to live and move around, with a large number of office staff to ensure the safety of the horses.

The site selection for the horse farm regime was based on the long-established empiricism of ancient China. Yi Shi states: "A horse must be properly housed ----- in a warm stable in winter and a cool one in summer. It is necessary to shave them regularly and not hurt the horses' ears or eyes or let them panic or be afraid." (马必安其处所……冬则温厩,夏则凉庆,刘剔毛器, 谨落四下,翏其耳目,无令惊骇。) $)^{35}$. It summarizes several vital requirements for the treatment of horses in ancient times. It is necessary to adjust the stables according to the change of seasons to avoid discomfort caused by the temperature of the horses, and the requirement of "Do not to let them panic or be afraid" is emphasized here.

The inscriptions of the LongYou state pasture of the Thirteenth Year of the Tang Dynasty ( 《大唐开元 十三年陇右监枚烦愧碑文》) records the following content:

"Clean spring water must always be available, and the stables should be cool and moist so that the horses can stand freely and cling to each other, following their nature. And they should be tamed, stamped, and harnessed to fulfill their instincts and talents." (洁泉美存, 库凉栈湿,㠻足而陆,交颈相靡 ,宜其性也。攻驹教眺,讲驭减仆,刻之剔之,羁之策之,就其才也 $)^{36}$

The inscriptions are generally used to record the classical events of ancient times and have the role of experience transmission. The requirements for horses and stables at that time were stringent. Not only must it be cold in summer and warm in winter, but it also must have enough space for them to move and jump.

The Song Dynasty and the Ming dynasty governments both had a scattering of war horses to the civilian population. The number and quality of horses produced under this model proved to be low, resulting in a significant decline in the country's military power. In addition, the decline in the overall quality of horses affected the operation of the state's administrative and military systems. The primary manifestation of this is the limited speed of information transmission and the significantly reduced efficiency of the central state apparatus in handling government affairs. ${ }^{37}$

The history of Yuan records:

"(In the Yuan dynasty) the pasture's border, the east can cross the Danluo, the north to reach the Huoli and Tuma, west to Gansu, south to Yunnan and other places. In all, there were 14 official farms, from Shangdu and Dadu to Yu you Bo Ya and Zelianqiedaier, a total of tens of thousands of miles." (其牧 地, 东越耽罗, 北逾火里秃麻, 西至甘肃, 南暨云南等地, 凡一十四处, 自上都、大都以至 玉你伯牙、折连怯呆儿，周回万里，无非牧地。 $)^{38}$

The state pastures of the Yuan Dynasty spanned thousands of miles, providing an excellent place for the breeding of horse species. The Yuan dynasty issued many strict bans, whose main prohibitions include: the prohibition of any outsiders to enter the horse farms and the prohibition of farming activities in the vicinity of the state pastures. For example, a ban issued in 1338 recorded: "It is strictly forbidden for any outsiders to enter the horse farms near the capital." ${ }^{39}$

\footnotetext{
32 (Yuan Dynasty) TUO, T., The history of the Song Dynasty, Beijing: China Book Bureau (1943) 4937.

33 (Song Dynasty) XIU, O., Complete Collection, Beijing: China Book Bureau (2001)1703.

${ }^{34}$ See Draft translation of the 'Tian Sheng Ling-Jiu Mu Ling', Journal of Chinese Ancient Legal Literature Studies \{3\}.00 (2015)299333. doi:CNKI:SUN:GDFL.0.2015-00-012.

35 (Qing Dynasty) MA, S., SHI, Y., (《绎史》卷一百五《战国第五·吴起仕相楚》), Beijing: China Book Bureau, (2002) 2766.

${ }^{36}$ (Qing Dynasty) DONG, G., Quan Tang Wen. Beijing: China Book Bureau, (1983) 2282.

${ }^{37}$ See SHANG, Y., The Evolution of National Horse Resources Genealogy and the Generation of Han and Tang Meteorology, Social Sciences in China, 8 (2020)154-177.

38 (Ming Dynasty) SONG, L. and others, The History of Yuan, Beijing: China Book Bureau (1976) 2533.

${ }^{39}$ See DING, C., Conflicts Between Agriculture and Pasture in Dadu Region and the Foundation of the Dual-capital System in the Yuan Dynasty, Journal of Tsinghua University (Philosophy and Social Sciences), 02 (2011) 94-106.
} 
By officially dividing the state pastures, the scattered state pastures system was unified into a welldefined horse farm regime, and the horses under such management bred well. Many good horse breeds were born in ancient times, and some species are still preserved today. ${ }^{40}$ Horse species became an important indicator of national strength in ancient times precisely because there was a detailed official system of dividing horse farms. The total number of horses reached seven hundred and sixty thousand in the forty years from Jingguan (627-649) to Linde (664-665). ${ }^{41}$

In addition to selecting vast land as state pastures, the government also attaches great importance to the environmental impact of horse farms in ancient times. Yuan Dian Zhang provides that horse farms shall not encroach on the people's land, interfering with agriculture: "everywhere there is a horse farm, local officials should be based on the specific circumstances, insert the marker, marking the boundaries of the farm. And residents shall not interfere with each other nor risk occupying the people's land." (诸站元有牧马草地,仰管 民官与本站官打量见数, 插立标竿, 明示界畔, 无得互相侵乱, 亦不得挟势冒占民田) $)^{42}$ "At that time, people from the south and the north, from all walks of life, gathered together, and the Mongolian army's horse farm occupied the people's land. (The central government) ordered Talichi to deal with the problem so that the military and the people could each have their place. "(时南北民户主客良贱杂糅, 蒙古军牧马草地互相占据 , 命塔里赤至其地理之, 军民各得其所 $)^{43}$ This approach confronted the dichotomy between horse farming and agricultural farming and harmonized the control by legal means to balance it.

In general, the center of horse breeding in ancient China was the state pastures. Personal horse breeding was either a supplementary form of government horse breeding or strictly prohibited by code or law. The widespread opening of personal horse breeding authorities is due mainly to the massive demand for horses in warfare. For example, in July of the twenty-ninth year of the Kangxi Dynasty, the government decreed to allow personal horse breeding: ${ }^{44}$ after the war, the slaughter, trade, and individual breeding of horses was prohibited. ${ }^{45}$ In some cases, horses could be donated to the state as ransom chips to reduce penalties. ${ }^{46}$

\section{Horse domestication regime}

We have already elaborated above regarding the physiological welfare, health welfare, and environmental welfare factors involved in the legal system of horse protection in ancient China. Looking back at the horse domestication regime, we can see that ancient ancestors were highly concerned about horses' behavior and psychological welfare. The regime then embodied a compassionate understanding of the individual animal and reflected the particular legal culture in the legal codes of successive generations.

In Article 201 of the Tang Code, the degree of wasting of the animal's body condition is linked to the responsibility of the relevant manager through quantitative measurement:

"201.2a-If animals put out to graze become emaciated, the basis for prosecution is calculated as ten parts. For one part, the punishment is twenty blows with the light stick, increased one degree for each further part.

201.2b-If the number does not constitute a full ten head, then for the first head, the punishment is thirty blows with the light stick, increased one degree for each further head.

201.2c-The maximum punishment is one hundred blows with the heavy stick in each case. ${ }^{47}$

This article establishes a vertical chain of responsibility in each state's pastures. Due to improper care resulting in losing a horse, any administrative personnel in the grazing process will be punished. And the principle of punishment using quantitative techniques, assuming a herd of one hundred horses, of which ten

\footnotetext{
${ }^{40}$ For example, nowadays, Chinese horse species can be divided into four main categories: grassland species; desert species; forest species; and mountain species. Many of these horses belong to ancient genetic biological resources, which are preserved to this day. See YANG, Z., CUI, T., Classification system of Chinese horses, Gansu Animal Husbandry and Veterinary, 02(1991):30-31. doi: 10.15979/j.cnki.cn62-1064/s.1991.02.027.

${ }^{41}$ (Ming Dynasty) QIU, J., Da Xue Yan Yi Bu, Shang hai: Shanghai Bookstore Press (2012) 321.

${ }^{42}$ CHEN, G. and others. Yuan Dian Zhang. Tianjin: China Book Bureau and Tianjin Ancient Books Press (2011)1238.

43 (Ming Dynasty) SONG, L. and others, The History of Yuan, Beijing: China Book Bureau (1976)3275.

${ }^{44}$ Qing Shengzu's Actual Records,(《清圣祖实录》卷148“康熙十二年九月壬子”条), Beijing: China Book Bureau (1985). Quoted from WANG, Y., Outline on Horse Administration in Qing Dynasty History Teaching, 6 (2016) 35-41.

45 (Qing Dynasty) LIU, J., Qing Dynasty Literature General Examination(《清朝文献通考》), Hangzhou:Zhejiang Ancient Books Press (1988) 6575.

${ }^{46}$ Qing Shengzu's Actual Records,(《清圣祖实录》卷 168“康熙三十四年九月己丑”条), Beijing: China Book Bureau ,(1985). Quoted from WANG, Y., Outline on Horse Administration in Qing Dynasty, History Teaching, 6 (2016) 35-41.

${ }^{47}$ JOHNSON, W., The Tang Code. Princeton: Princeton University Press. (1979)187.
} 
horses are not adequately cared for and thinning, will be calculated as one point, punished by twenty blows with the light stick. And for less than ten, the punishment is more severe, causing an emaciated horse to be penalized by thirty blows with the light stick. The chief of the state pastures is responsible for the herd under them, even if not directly raised by them, and subject to collective punishment. It's the method of calculating the penalties for emaciating other animals, and the punishment is less severe if the object is sheep.

The domestication of horses was strictly regulated in the Tang Code as a mandatory prerequisite for official horse riding:

"All cases where government horses are not trained for the purpose for which they are used are punished by twenty blows with the light stick for the first horse, increased one degree for each further five horses, and with a maximum punishment of one hundred blows with the heavy stick." ${ }^{48}$

It is expressly stipulated that the age of training for horses is two years old. In the case of herding officers who manage horse breeding stock, they are equipped with ten special training assistants when they need to practice. And five of them become one shift, with two shifts rotating. The 1st of March and the 30th of April are the handover dates. ${ }^{49}$ For the imperial horses, trainers had to follow the following code when taming them: "The official trainer must train imperial horses with respect, and no one must whack them if it is not necessary for training."(凡御马必敬而式之, 非因调习, 不得捶击) ${ }^{50}$ The attitude is an extension of the inviolability of imperial power, but at the same time can also reflect the vital status of horses at that time.

The Tang Dynasty established keeping horses in stables and training them in the field in terms of domestication methods. ${ }^{51}$ When training in the area, it mainly imitated the training of army marching, and the relevant record reads, "The rhythm of eating, resting and stopping of the horses was the same as the Turkic pattern. The trainers took the horses to move with the changing seasons of water and grass."(饮食居止，一 同突厥, 随逐水草) ${ }^{52}$ Although the ultimate goal of horse domestication is artificial use, this dynamic training model meets the needs of horses by nature for all aspects of environment, season, temperature, and diet. In addition, the "East Palace," where the crown prince stayed, also has exceptional official staff for horse domestication. $^{53}$

Even after the domestication of horses, it did not mean that they did not need to be strictly protected. On the contrary, Article 199 of the Tang Code strictly regulates the reasonable use of horses. ${ }^{54}$

The official code of the Yuan Dynasty, the Genghis Khan Code, states, "It is forbidden to beat the head and face of a horse. Between battles, horses are to be put on the grass to satiate themselves, and riding is forbidden."(禁打马之头面。战斗间隙, 要放马于草地饱食, 禁止骑乘) ${ }^{55}$ The conditions for the treatment of horses are regulated on a legal level, and inhumane acts against horses are strictly prohibited. Even the Yuan Dynasty also issued a decree banning the use of horses to tug the carriage.

Moreover, the consequences of legal responsibility involve the most severe death penalty, and the stringency of the code is evident. In the record of the mission to Mongolia, it is written that "Anguo has excellent geographical conditions, with abundant water and grass, suitable for raising sheep and horses. ...... horses are grown for three years before riding. ...... With the season of grass and trees withering, they are placed in the wilderness for grazing." (鞍国地丰水草, 宜羊马。其马初生一二年......却养三年而后再乘 骑。......随其草之青枯, 野牧之) ${ }^{56}$ This passage means that for the horse training need to wait until the horse grows strong to three years old before starting, in other words, is following the natural rule of growth of horses and training activities, not to let the newborn horse bear the burden.

The Yuan Dynasty's emphasis on horses had its intrinsic ethnic background, as directly recorded in the History of Yuan: "The Yuan Dynasty originated in the northern highland. The people were always good at riding and archery. It was because of this advantage that the Yuan Dynasty was able to win the world." (元起

\footnotetext{
48 JOHNSON, W., The Tang Code. Princeton: Princeton University Press. (1979)187.

49 JOHNSON, W., The Tang Code. Princeton: Princeton University Press. (1979)188.

50 (Tang Dynasty) LI, L., TANG, L.D., CHEN, Z., Proofreading. Beijing: China Book Bureau, (1992) 330.

${ }^{51}$ See SHANG, Y., The Evolution of National Horse Resources Genealogy and the Generation of Han and Tang Meteorology, Social Sciences in China, 8 (2020)154-177.

52 (Tang Dynasty) WEN, D., Da Tang Chuang Ye Qi Ju Zhu(《大唐创业起居注》), Shanghai: Shanghai Classics Publishing House (1983) 2.

53 (Song Dynasty) XIU, O., The New History of the Tang Dynasty, Beijing: China Book Bureau, (1975)1299.

${ }^{54}$ JOHNSON, W., The Tang Code, Princeton: Princeton University Press (1979) 184.

${ }^{55}$ See QI, G., Re-discussing Genghis Khan's Great Zasar, Inner Mongolia Social Sciences, 06 (1996): doi:CNKI:SUN:NMGR.0.199606-006.

${ }^{56}$ XU, Q., Shen Zengzhi's Historical and Geographical Works, Beijng: China Book Bureau (2019) 271.
} 
朔方, 俗善骑射, 因以弓马之利取天下 $)^{57}$ As a non-Han nationality and ruling the Central Plains, the Mongolians valued horses as a national habit and a basis for the rule. ${ }^{58}$

Specifically, the classical codes of ancient China all provide for many methods of horse domestication, which are based on a significant accumulation of experience and contain many eco-ethical regulations. Such as "Until the west wind comes - People should feed the horses a little water and grass until they lose their fat." (直至西风将生...啖以些少水草,经月膘落) ${ }^{59}$ This method is described in Hei Da Shi Lue as " tethered horse, "a method of domestication that balances horses' diet and improves their physiological quality under their physiological structure.

In the standing position, the horses can save a lot of physical strength; Hei Da Shi Lue also contains after the "tethered horse": "People ride these horses for hundreds of miles, and they don't even sweat. Therefore, such horses have stamina and can be used for fighting. "(而日骑之数百里, 自然无汗, 故可以耐远 而出战 ${ }^{60}$ Based on the tethered horse, people then train the horses to run. This tension and relaxation method of training responds to the horse's behavioral needs and enhances the horse's physical function.

In addition, Yi Shi points out: "People should train their horses so that they know how to run and gallop. At the same time, horses should also be allowed to rest and maintain a training rhythm that is in keeping with their nature. People and horses should care for each other so that horses can be better used."(习其驰逐, 闲其 进止,人马相亲, 然后可使 $)^{61}$ The domestication of horses must be built based on living in harmony with horses.

\section{Institutional management regime}

For the management of horses, the relevant ancient institutions played a vital role in ancient times. They used the administrative force to carry out horse herding work. Successive dynasties had corresponding official administrative agencies and administrators to manage various matters of horses, and codes expressly provide their duties. Accordingly, ancient China formed a unified horse management system and set the corresponding legal responsibilities. For example, the Tai Pu Si (the Tang Dynasty) and Shang Xun Yuan (the Qing Dynasty) have formed a rigorous scientific horse management process.

The regime of horse management institutions originated in the Zhou dynasty, and the Rites of Zhou recorded: "Jiaoren," "Quma," "Wuma," "Mushi," and other specific officials were in charge of the breeding, management, and medical care of horses. ${ }^{62}$ In the Qin Dynasty, the Qin Law stipulated in legal form the specific positions of horse management personnel such as Jiusefu and strictly defined the scope of responsibility. ${ }^{6}$ The horse management institutions did not simply carry out care and feeding but divided the duties of the horse management agencies' personnel according to different situations, such as the types of horses and geographical locations.

For example, during the Yuan dynasty, Tai Pu Si was in charge of Atas' horses and saddle making. ${ }^{64}$ Du Zhi Jian had to store fodder for horses and camels. ${ }^{65}$ Jing Zheng Jian was in order of the signage and other chores around the farm. ${ }^{66}$ As mentioned above, the Tang Code stipulates that in September and October every year, Tai Pu Si had to review the national horse farms, assessing the condition of pasture, the number of horses, and a series of indicators. It even involved the fat and lean condition of each horse. ${ }^{67}$

In addition to taking care of the horses and regularly counting the number of horses, the management institutions must also enforce the recovery of compensation for those who cause the loss of horses, which is contained in the Code of Great Ming Dynasty: "If a horse is lost, weak or dead, the institution must recover compensation from the person who is in charge of it " (瘦倒失者, 比较、追赔) ${ }^{68}$ And there is the abuse of horses by some nobles, which is beyond the power of the institutions, there is a personal edict of the emperor

\footnotetext{
57 (Ming Dynasty) SONG, L. and others, the History of Yuan, Beijing: China Book Bureau, (1976) 2553.

${ }^{58}$ See DING, C., Conflicts Between Agriculture and Pasture in Dadu Region and the Foundation of the Dual-capital System in the Yuan Dynasty, Journal of Tsinghua University (Philosophy and Social Sciences), 02 (2011) 94-106.

${ }^{59}$ XU, Q., Shen Zengzhi's Historical and Geographical Works, Beijing: China Book Bureau (2019) 287.

${ }^{60}$ XU, Q., Shen Zengzhi's Historical and Geographical Works, Beijing: China Book Bureau (2019) 287.

${ }^{61}$ (Qing Dynasty) MA, S., SHI, Y., Beijing: China Book Bureau (2002) 2767.

${ }^{62}$ (Qing Dynasty) RUAN, Y., Proofreading, Commentary on the Thirteen Classics/Shi San Jing Zhu Shu, Beijing: China Book Bureau (2009) 668.

${ }^{63}$ See WANG, Y., Chronology of Qin and Han History, Nanjing: Phoenix Press (2011) 482.

${ }^{64}$ (Ming Dynasty) SONG, L. and others, the History of Yuan, Beijing: China Book Bureau, (1976) 2288

65 (Ming Dynasty) SONG, L. and others, the History of Yuan, Beijing: China Book Bureau, (1976) 2292.

${ }^{66}$ (Ming Dynasty) SONG, L. and others, the History of Yuan, Beijing: China Book Bureau, (1976) 2295.

67 (Tang Dynasty) LI, L., TANG, L.D., CHEN, Z., Proofreading, Beijing: China Book Bureau, (1992) 486.

${ }^{68}$ (Ming Dynasty) LI, D., SHEN, S., Code of Great Ming Dynasty, Yangzhou: Guangling Book Club (2007) 2137.
} 
to regulate in Yuan Dynasty: "The king's nobles were allowed to use three horses if they wanted to ride posthorses, and they could not exceed the limit of four horses for long-distance travel. "(诸王驰驿, 许乘三马, 远行亦不过四 $)^{69}$ There were also strict regulations to prevent theft by the personnel of the institution itself, and the Genghis Khan Code stipulates: "This code strictly forbids scavenging and theft (by horse management personnel). In addition to compensation, those who steal horses must pay a fine, and if they fail to pay the fine will be executed. "(禁拾遗和偷盗。盗马者除必须赔偿外，并课以罚金，不能缴纳罚金者处死 $)^{70}$

As for the specific management process, the history of yuan has the following record:

"Concentrated herds of hundreds or thousands of horses, some with only a few dozen. Their left leg is branded with an official seal, and they are called large seal horses - these official seals, with names such as Bing $\mathrm{Gu}$, Bian $\mathrm{Gu}$, and others. Responsible for grazing people called $\mathrm{Ha}$ Chi, Ha Lachchi; the corresponding official positions are Qian hu and Bai hu, generally passed on from father to son. Since summer and winter, (horse grazing) should follow the specific conditions of the environment and move to graze in places with abundant water and grass. In October, people then move the herd back to their respective areas. The government sent officials to inspect in September and October to examine the number of horses. The officials then produced manuals in several languages, including Mongolian, HuiHui, and Chinese. (But the total number of horses at that time was no recorded). If horses in the herd died of the disease up to three, the herder in charge had to compensate for one large female horse; for two that failed, he compensated for one two-year-old horse. If one dies of disease, he compensates one sheep. If the person does not have a horse, he will use a sheep, a camel or a cow as a credit." (马之群 ，或千百，或三五十，左股烙以官印，号大印子马。其印，有兵古、贬古、阔卜川、月思古 、斡栾等名。牧人曰哈赤、哈刺赤; 有千户、百户，父子相承任事。自夏及冬，随地之宜， 行逐水草，十月各至本地。朝廷岁以九月、十月遣寺官驰驿阅视，较其多寡，有所产驹即烙 印取勘, 收除见在数目，造蒙古、回回、汉字文册以闻，其总数盖不可知也。凡病死者三， 则令牧人偿大牝马一，二则偿二岁马一，一则偿牝羊一，其无马者以羊、驼、牛折纳。 $)^{71}$

The Tang Dynasty's state pasture regime was one of the better regimes for managing horse institutions, with a systematic process for equine management staffing. Not only did it cover universal selection and turnover procedures, but in the event of a shortage of staff, the government would issue a "decree on seeking staff" to supplement the staffing of the supervisors. In the Tang Dynasty, there was an official decree in 715 A.D.: "If there is a vacancy in the governor of each region, the local envoy shall be entrusted with the selection of the person in charge of shepherding as soon as possible. Subsequently, the local supervisors must report to the agency responsible for selecting supervisory officials for unique verification and additional officials." (开 元三年四月八日敕。诸道牧监官。有阔紧要者。委本使简择明闲牧养者。奏付选司勘实补拟。 $)^{72}$

Since many of the Tang dynasty shepherds were slaves, the laws and codes also provided that they could change their status by breeding horses for the government over a long period. However, even if they became commoners, they were not allowed to leave the horse farm. ${ }^{73}$ The Tang dynasty had a detailed reward mechanism for those responsible for feeding horses, such as "each state pastures, when counting the number of horses, rewarded with a silk cloth for an extra foal. "(诸牧，马剩驹一匹，赏绢一匹。) ${ }^{74}$ And, the reward mechanism does not exclude slaves.

The horse management regime has been formed in ancient China since the pre-Qin dynasty. The management of horses has been carried out systematically in the form of official administrative institutions. The functions of horse management institutions cover all aspects. In addition to the daily aspects of feeding, taming, and medical treatment, there are also official and administrative institutions specializing in the manufacture of harnesses and saddles. Official institutions also manage even the sources of feed for horses. Such systematic management from top to bottom is the concrete embodiment of China's ancient horse politics.

\footnotetext{
69 (Ming Dynasty) SONG, L. and others, the History of Yuan, Beijing: China Book Bureau (1976) 44.

${ }^{70}$ Inner Mongolia Institute of Canonical Law and Sociology, The Genghis Khan's Code and Original Treatise, Beijing: Commercial Press, (2007)10.

71 (Ming Dynasty) SONG, L. and others, The History of Yuan, Beijing: China Book Bureau (1976) 2553.

72 (Song Dynasty) WANG, P., Tang Hui Yao, Beijing: China Book Bureau (2017) 1146.

${ }^{73}$ Proofreading by the Tianyi Ge Museum and the Tiansheng Order Collation Group, Institute of History, Chinese Academy of Social Sciences, Proofs of the Ming Banknotes of the Tian Sheng Order in the Tianyi Ge Collection (with a study of the restoration of the Tang Order) Volume 2（《天一阁藏明钞本天圣令校证 (附唐令复原研究)》Beijing: China Book Bureau (2006) 299.

${ }^{74}$ Proofreading by the Tianyi Ge Museum and the Tiansheng Order Collation Group, Institute of History, Chinese Academy of Social Sciences, Proofs of the Ming Banknotes of the Tian Sheng Order in the Tianyi Ge Collection (with a study of the restoration of the Tang Order) Volume 2, Beijing: China Book Bureau (2006) 295.
} 
In addition, there is a form of internal oversight in the design of the regime, the history of ming has the following record:

"(Tai $\mathrm{Pu} \mathrm{Si}$ ) is responsible for various border areas where the cantonment of horse management and follow the Ministry of War orders. Tai Pu Si is responsible for the use of horses, horse branding, horse breeding, horse statistics. Every spring and autumn, Tai Pu Si needs to check the changes in the total number of horses and their quality, once every three years, systematically. No other administrative institutions may be involved. If there is any impairment of horses, the personnel will be punished by the Ministry of War." (掌各边卫所营堡之马政, 以听于兵部。凡骑操马匹印烙、俵散、课掌、杽 牧, 以时督查之。岁春秋, 阅示其增耗、齿色, 三岁一稽比，布、按二司不得与。有㾑损， 则听兵部参罚。 $)^{75}$

Such a regime of supervision made the relevant administrative institutions administratively efficient and subject to internal management. In $713 \mathrm{AD}$, horses decreased from more than 700,000 in Zhenguan to Linde to 240,000. The main reason is the negative impact of war and the economy on the operation of the management mechanism.

\section{Horse breeding and medical care regime}

The thorough protection of horses in ancient China can also be seen in supporting medical care, nursing, and breeding regimes. These support regimes are based on meeting the basic needs of horses and on a higher level of welfare protection.

First of all, the breeding regime of horses has a strict operating procedure. The Rites of Zhou states, "Let the horses mate with each other in the second month of spring."(中春通淫) ${ }^{76}$ People kept male and female horses in separate groups until the breeding season. The ancient government also established a scientific breeding record regime, detailing the date of breeding and delivery of horses: "The prefectures, states, and counties all made record booklets with the relevant proof seals, which were given to the officials responsible for managing horses, and they used these seals to mark the dates of mating and childbirth of horses." (府、州 、县置群盖文簿立印信,与管马官吏收掌、提调,逐日盖过次数、定驹日期等 $)^{77}$

The ancient dynasty also established a separate regime of medical care for horses. The traditional medical experience, generally accepted, was also fixed by the ancient people with laws to form operational norms. In ancient times, the medical treatment of horses was separated from the medical treatment of animals and developed professional protection work. Yuanheng's Collection of Healing Horses is the most comprehensive collection of horse medical treatment in ancient China. ${ }^{78}$ There are customary practices for horse medical treatment, which are explicitly stipulated in the codes or laws, some of which are passed down from experience, such as "Anyone who wants to ride horses can't feed them too much. When unsaddling a horse, you must use the horse rope to make the horse lift its head and wait until its breath is steady and its hooves are cold before you can ride them." (凡驰骤勿饱, 凡鞍解, 必索之而仰其首, 待其气调息平, 四 蹄冰冷, 然后纵其水草 $)^{79}$

And Article 198 of the Tang Code stipulates that:

"198.1-All cases of being in charge of government animals that become sick and their care and treatment are not according to the rules are punished by thirty blows with the light stick.

198.2-If for this reason any animal dies, the punishment is forty blows with the light stick for the first animal, increased one degree for each further three animals, with a maximum punishment of one hundred blows with the heavy stick." 80

As mentioned above, the Tang Code also stipulates that if animals such as horses and cattle fall ill during transportation, the nearby governments must provide remedial measures and grain and medicine. The

\footnotetext{
75 (Qing Dynasty) ZHANG, T., The History of Ming, Beijing: China Book Bureau (1974) 1845.

${ }^{76}$ (Qing Dynasty) RUAN, Y., Proofreading, Commentary on the Thirteen Classics/Shi San Jing Zhu Shu, Beijing: China Book Bureau (2009) 1860.

77 Quoted from AN, L., A brief history of the development of animal husbandry in ancient China (continued), Agricultural Archaeology, 02 (1989) 341-350. doi: CNKI: SUN: NOSE.0.1989-02-064.

78 (Ming Dynasty) YU, B., The Yuanheng's Collection of Healing Horses/Yuan Heng Liao Ma Ji, Beijing: China Book Bureau (1957).

${ }^{79}$ XU, Q., Shen Zengzhi's Historical and Geographical Works, Beijing: China Book Bureau (2019)287.

${ }^{80}$ JOHNSON, W., The Tang Code, Princeton: Princeton University Press (1979) 183.
} 
supply of this fodder is explicitly stipulated in the ordinance, considering it is intended for sick animals. Fodder is good for digestion. If the officials didn't treat animals following the code, the officials were punished with penalties. And there was an aggravating circumstance of intentionally causing the death of the animals. The rule of this article is strict to protect the integrity of the official animals and avoid missing the opportunity to rescue animals due to the slackness of the local response personnel.

For the usual care of horses, there are a series of methods, such as installing the horseshoe hoof iron to protect the horse's hoof and reduce the effectiveness of wear and tear. The practice can be traced back to the Han Dynasty. ${ }^{81}$ And the Pen Tie Weng Lun states that the saddle can also play a role in reducing the burden on the horse: "(horse's) saddle and bridle can make the horse more suitable for galloping, this equipment weighs no more than seven or eight chins. The design of the saddle imitates the wings of geese. The front of the saddle is raised, while the rear is flat. And horses will not be injured when turning and cornering." (其鞍 暂轻简以便驰骋, 重不盈七八斤, 鞍之雁翅齿, 前坚而後平。故折旋而不伤 $)^{82}$

The starting point of the horse breeding and medical care regime is to use horses for activities better. It is based on the premise of conforming to the nature of horses through scientific methods to reduce the burden of horses. This model of human-horse harmony maintains the basic needs of humans and protects horses as a species accordingly. It reflects ancestors' ecological and ethical concerns and extends the scope of the moral world to horses.

\section{Setting of legal liability}

To measure the degree of protection for horses in ancient China, we must analyze from the legal liability settings. The severity of legal liability reflects the importance that legislators of the time attached to horses. Today, In China, animals are defined as lawful "things" and "property," and there are minimal legal means to prosecute people who harm or abuse animals. In contrast, in ancient times, the legal protection for horses and animals was already stringent.

Long Gang Qin Jian says: "No one shall set traps and other injurious organs on the roads where cattle and horses walk." (诸马牛到所, 冊敢穿阱及置它) ${ }^{83}$ The legal accountability regime for theft and killing of horses has been reflected in the record; and in the Yuan Dynasty under the rule of the "nation on horseback", the legal consequences for theft, injury, and killing of horses were more comprehensively and severely stipulated. According to our statistics, there are as many as 23 criminal regulations related to horses in the History of Yuan. ${ }^{84}$

As the legislation on horse protection in Yuan, Song, Ming, and Qing dynasties follows the Tang Code, we choose it as a reference. The most important one is Article 203 of the Tang Code, which reads as follows:

"203.1a-All cases of intentionally killing government or private horses or cattle are punished by one and one-half years of penal servitude.

203.1b-If the punishment for the value of the illicit goods (i.e., the value of the animal) is heavier, or if other domestic animals are killed, then the lost value of the animal is calculated and punished as comparable to robbery." 85

Penalties for persons and compensation for property go hand in hand, and the legislative purpose behind them is to protect cattle and horses as important state and private property. In addition, there are many other violations against horses that are regulated in separate articles in the Tang Code. The relevant rules regarding horses in state-owned stagecoaches are Article 127 "Taking an Excessive number of Post Horses," Article 128 "Taking the Wrong Route while Riding Post Horses," and Article 129, "Carrying Private Articles while Riding Post Horses." 86 The theft of horses is also explicitly provided for in Article 279:

"All cases of robbery and killing of government or private cattle or horses are punished by two and onehalf years of penal servitude." 87

\footnotetext{
${ }^{81}$ (Han Dynasty) HENG, K., Salt and Iron Theory/Yan Tie Lun Jiao Zhu, Beijing: China Book Bureau (1992) 350-351.

${ }^{82}$ XU, Q., Shen Zengzhi's Historical and Geographical Works, Beijing: China Book Bureau (2019) 288.

${ }^{83}$ WANG, H., WANG, W., Chronological Supplement to Qin Unearthed Documents, San Qin Press (2014) 566.

${ }^{84}$ (Ming Dynasty) SONG, L. and others, the History of Yuan, Beijing: China Book Bureau (1976).

${ }^{85}$ JOHNSON, W., The Tang Code. Princeton: Princeton University Press. (1979) 188.

${ }^{86}$ JOHNSON, W., The Tang Code, Princeton: Princeton University Press. (1979) 95-98.

${ }^{87}$ JOHNSON, W., The Tang Code, Princeton: Princeton University Press. (1979) 289.
} 
The special status of cattle and horses in the country's military is clearly stated in the sub commentary of this article: "The country's armies use horses and cattle. Therefore they are different from other domestic animals." ${ }^{88}$ There is an example of an official stables officer who stole more than a dozen official horses and defected, and the prince was directly responsible for their capture. ${ }^{89}$

In the Tang Code, liability for violations of the use of the load limit for horses is even clearly set out as follows:

"In all cases where a person uses a government horse, ox, camel, mule, or donkeys, the private possessions carried must not exceed ten chin(A chin was approximately one and one-half English pounds) in weight. Violations will be punished by ten blows with the light stick for the first chin, increased one degree for each further ten chin, with a maximum punishment of eighty blows with the heavy stick." 90

The provisions to combat the crime of horse theft in the Yuan dynasty code has a total of five articles, respectively, related to the theft of horses and cattle relatives, theft of horses and cattle by slaves, theft of horses and cattle by thieves, and the punishment of theft by ordinary people. ${ }^{91}$

As mentioned above, the operation of the horse management agencies determined the development of the horse breeding industry. Article 196 of the Tang Code provides in detail the joint liability of all levels of responsibility for the death and loss of animals in the official horse farm. ${ }^{92}$ And if warhorses were thin and unfit for use, the person responsible would also be punished. In 816 A.D., the supervisor of the Loufan state pasture was reduced to a slave for this reason. ${ }^{93}$ Many such documents from the Qing Dynasty prove that the officials concerned had to be held accountable when horses were poorly bred. In April and August of the 35th year of the Kangxi era, the Kangxi Emperor dismissed two military officials in succession, both because the military horses were thin and weak. ${ }^{94}$

\section{Conclusion and Prospects}

\subsection{The dynamic relationship between the legal system of horses and the national economy in ancient China}

We can conclude that the legal system for the management and protection of horses in China has been in place since pre-Qin. With the codes' development, it peaked in the publication of the Tang Code, forming a specific and perfect overall regulatory system. Wang Fuzhi also commented, "The reason why the Han and Tang dynasties flourished and were strong was because of their strong animal husbandry."( 汉、唐之所以能 张者, 皆唯畜牧之盛也 $)^{95}$ The horse management system and breeding technology of the Tang Dynasty reached the peak of ancient times. Therefore, in this paper, we chose Tang Dynasty documents to analyze historical materials and laws.

The main distribution of laws is as follows: the codes related to horses in the postal system are distributed in the "Administrative Regulations." (《职制律》) The regulations associated with protecting animals as official and private property are written in the regulations of "The Public Stables And Warehouses."(《厩库律》) There are 28 articles in total. Most of these codes are directly related to the protection and management of horses and other animals. For example, the Tang Code has a clear limit on the maximum weight of official horses, oxen, camels, mules, and donkeys when used to carry goods. Article 199 of the Tang Code, "Using Government Animals for the Transportation of Private Possessions," stipulates that when a person uses a government animal, the private possessions carried must not exceed ten chin. ${ }^{96}$

This provision in the Song Code is not changed. Because of the ethnic background of the Yuan Dynasty, the horse has a series of more stringent protection norms. But the later Ming and Qing dynasties, in the development of the code, re-enacted the legislative model along with the Tang dynasty, in the specific provisions set out in the Tang dynasty as a blueprint.

\footnotetext{
${ }^{88}$ JOHNSON, W., The Tang Code, Princeton: Princeton University Press. (1979) 289.

${ }^{89}$ (Song Dynasty) WANG, P., Tang Hui Yao, Beijing: China Book Bureau (2017) 1303.

${ }^{90}$ Wallace Johnson, The Tang Code, Princeton: Princeton University Press. (1979) 184.

${ }^{91}$ (Ming Dynasty) SONG, L. and others, The History of Yuan, Beijing: China Book Bureau (1976) 2663.

92 JOHNSON, W., The Tang Code, Princeton: Princeton University Press (1979) 178-181.

93 (Song Dynasty) WANG, P., Tang Hui Yao, Beijing: China Book Bureau (2017) 1146.

${ }^{94}$ WANG, Y., Outline on Hors e Adminis tra tion in Qing Dynasty, History Teaching, 6 (2016) 35-41.

95 (Ming Dynasty) WANG, F., Er Meng, Beijing: China Book Bureau (1956) 12.

${ }^{96}$ JOHNSON, W., The Tang Code, Princeton: Princeton University Press (1979) 184.

40 Derecho Animal. Forum of Animal Law Studies, vol. 12/3
} 
There are 18 articles related to the management of post and passenger horses in the Daming Code. In addition, the Daming Code set up 11 articles of the public stable, excluding from it those articles in the Tang Code - The Public Stables And Warehouses that deal with the storage, equipment, and other matters unrelated to animals. Accordingly, the Ming Dynasty dedicated chapters to the legal system for managing horses and other animals, mainly concerning herding, breeding of horses, statistics and counting, medical treatment, use limits, domestication of horses, and prohibition of animal slaughter. And for horse breeding matters, the Daming Code legislated separately for them, further improving the Tang Dynasty legislation. The Qing Code is closer to the Daming Code in the setting of specific horse-related legal names. However, in general, the legislative framework and model have not deviated from the foundation laid in the Tang Dynasty. The changes mainly lie in the improvement and supplementation of the legal system related to horses.

However, the development of horse breeding in the country is positive for the individual horses and breeding stock. It faced remarkable contradictions; first, the result of horse breeding directly affected agriculture. The official horse farms of the Tang Dynasty were vast, and the stock of horses was counted in hundreds of thousands. And it is recorded in the Tang Hui Yao that the emperor issued a royal decree in the 11th year of Tianbao: "No one shall set up private grazing land within a 500-li(In the Tang Dynasty, 1 Li was equal to about 530 540 meters) radius of the two capitals. All existing grazing lands shall be changed to officially managed." (两京去城五百里内。不得置私牧地。如有。一改官牧。) ${ }^{97}$ The emperor directly prohibited the setting of the people's grazing land near the capital. In addition, there is a recorded example of the need to abolish more than 400 dumps of all the people's fields because of 3,300 grazing horses. However, the final decree was not passed because of the outsized impact on agriculture. ${ }^{98}$ After the An-shi Rebellion, the economy of the Tang Dynasty was in complete decline, and the people were not living well. In 837A.D., the local governor's memorial letter stated that in order to prevent the Turk from seizing the horses, it was necessary to find a secure place to raise the horses. Still, it was also essential to avoid the fields used by the people for farming ${ }^{99}$ Even the Yuan Dynasty later established the patrol regime, led by the emperor to migrate grazing horses, and its purpose was to solve the contradiction between agricultural farming and grazing. ${ }^{100}$ The conflict between horse breeding and agrarian development affected people's livelihood. A saddening example of this occurred in the Han Dynasty. At that time, the state levied a tax on children between the ages of 7 to 14, called "kou qian." The amount of this tax was initially 20 qians (48 B.C.), but was later increased by 3 qians to supplement the expenses of carriages and horses used for armaments. As a result, many lowincome families killed their children after birth because they could not afford such a high "kou qian." ${ }^{101}$ To maintain such a systematic, complete, and strict horse protection and management system required huge national economic expenditure. The Tong Dian recorded in the Tang Dynasty: "The expensive cost of feeding one horse is enough to feed five soldiers. "(一马之费, 足以养步卒五人。) "The cost of taming a horse is equivalent to the daily expenses of six people in a family. "(一马伏枥, 当中家六口之食。) ${ }^{102}$ The annual cost of post stations in Yunnan during the Qing dynasty was as high as 30,000 to 40,000 taels, and this was limited to the portion that could be counted. At the same time, a large part was borne by local government, private individuals, which could not be calculated. ${ }^{103}$

Secondly, ancient China established legal regimes to protect and manage horses, but it still regarded horses as an essential tool. Still, it only incorporated love or sympathy when using them. We can summarize it in the closed management of horse breeding sources in ancient China. The Book of Han records that horses higher than five feet nine chis $\left(1 \mathrm{chi}\right.$ equals approximately $33.33 \mathrm{~cm}$ ) were forbidden to come out. ${ }^{104}$ The ancient law expressly forbade the departure of good horse breeds, the purpose of which was to prevent foreigners from acquiring them and posing a threat to the feudal state.

On the contrary, the state's source of horses is partly from import trade. During the Qing Dynasty, there were four primary sources of official horses: the tea and horse trade, tribute horses, donated horses, and horses obtained from market transactions. ${ }^{105}$

In ancient China, although ancient codes have established the legal system to protect both individual

\footnotetext{
${ }^{97}$ (Song Dynasty) WANG, P., Tang Hui Yao, Beijing: China Book Bureau (2017) 1146.

98 (Song Dynasty) WANG, P., Tang Hui Yao, Beijing: China Book Bureau (2017) 1146.

99 (Song Dynasty) WANG, P., Tang Hui Yao, Beijing: China Book Bureau (2017) 1147.

100 (Yuan Dynasty) ZHOU, N., The Collection of Tian Xia Tong Wen (《天下同文集》卷一六《赋》), Photocopy of Wenyuange's Si Bu Cong Kan。

${ }^{101}$ LIU, X., Han Dynasty Tax on Six Animals: Origin, Implementation and Effects, The Journal of Chinese Social and Economic History, 2 (2014) 1-6.

102 WANG, X., The Study of the Prison in Tang Dynasty, Master's Thesis, Shanxi University (2020) 39.

${ }^{103}$ ZHAO, P., Effects of the Ming Dynasty's Post System on Society and Economy in Southwest China, Journal of Guizhou Normal University(Social Sciences), 6 (2018) 25-108.

104 (Han Dynasty) BAN, G., The book of Han, Beijing: China Book Bureau (2005) 157.

${ }^{105}$ See WANG, Y., Outline on Hors e Adminis tra tion in Qing Dynasty History Teaching, 6 (2016) 35-41.
} 
horses and their breeding stock, it had both positive and negative attributes. The positive aspects of the system were the advancement of legal care for horses and the promotion of the centralized management and military preparedness of the feudal state. However, we must note that the basis for realizing such a legal system with a rigorous design was the appropriation of the agricultural economy. Therefore, in the dynasties with overall solid-state power, this system functioned well and mutually reinforced state development. However, in times of national turmoil, this system tended to affect the economy and people's livelihood and eventually disappeared with the demise of the feudal state.

\subsection{Modern Chinese Animal Welfare Legislation and Legal Tradition}

Because of the special status of horses, China developed a legal management and protection system for horses from birth to death, from breeding to use. Within these regulations, many legal requirements were derived that coincide with modern animal welfare doctrines, thus forming the protection concept for horses and other similar livestock. Behind this legal culture is the acceptance of horses as animals in the human moral world based on "the harmony between human and nature." Severe legal consequences have been set for generations, and the consequences of infringing on horses go far beyond the general protection of property.

Thousands of years ago, the concern for animals' emotions, moods, and nature was explicitly stated in successive codes. Although their ultimate purpose was still based on the instrumental use required for the development of feudal society, it is worthwhile to learn from them today. The legal system for the protection of horses in Chinese history profoundly influenced the East Asian legal system. The Tang Code is regarded as the fundamental source of the East Asian legal system. Chinese history has developed a legislative culture of compassionate understanding and legal protection for horses and other animals. This cultural tradition should be passed on in contemporary times to create a place for animals in the legal system and protect them from unnecessary suffering.

In the context of ancient China's agricultural economy, legal protection for animals such as horses required huge economic expenditure. As mentioned above, in some periods, the expenses for feeding one horse could equal the living needs of 5-6 people. However, today, when technology is highly developed, the welfare protection of animals such as horses is no longer in conflict with the achievement of human wellbeing. In some ways, the improvement of animal welfare is even in line with the requirement for improving human society's overall standard of living.

Based on this, the ancient Chinese legal protection system for horses gives us at least the following empirical resource:

First, there exists a large and straightforward culture of protection concept for horses and other animals in Chinese tradition. It indicates that there is a conceptual basis for animal protection in traditional Chinese culture. Therefore, animal welfare legislation in China does not face conceptual obstacles.

Second, in ancient times, the realization of animal welfare may have affected the agricultural economy. However, this is more reflective of the fact that today, in a period of high economic development, animal welfare is in line with the direction of human society, which contributes to a more civilized society. For example, after the COVID-19 outbreak, the improvement of animal welfare is under the normative requirements of public health and disease control.

Third, the protection of horses in ancient China was closer to the protection of the instrumental value of horses, but whatever the ultimate goal of animal protection, the path to its realization improved the situation of the animal as much as possible. Thus, even if we are protecting animals from some level of exploitation, this is not incompatible with improving the situation of animals. 